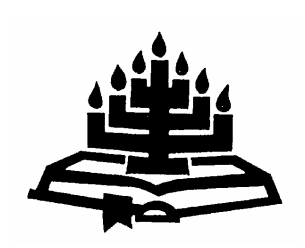

\title{
Die aanwending van Rolf Zerfass se handelingswetenskaplike model in prakties-teologiese teorievorming - 'n gereformeerde perspektief
}

\author{
F.W. de Wet \\ Skool vir Kerkwetenskappe \\ Potchefstroomkampus \\ Noordwes-Universiteit \\ POTCHEFSTROOM \\ E-pos: kwsfwdw@puk.ac.za
}

\begin{abstract}
Utilising Rolf Zerfass's operational scientific model in developing practical-theological theory - a reformed perspective
\end{abstract}

Rolf Zerfass's operational scientific model for correcting Christian-ecclesiological praxis is frequently utilised in practicaltheological research at the North-West University. At face value Zerfass's model seems to serve as an ideal framework in guiding a practical-theological study through all the relevant methodological phases - emphasising the cycle needed to move from a problematic Christian-ecclesiological praxis to a new praxis and offering a clear vision on hermeneutical interchange between theological tradition and operational praxis; theology and social sciences. A practical-theological researcher operating from a reformed frame of reference should, however, assess to what extent Zerfass's model could serve his/her own unique vision on points of departure and goals set for developing practical-theological theory. The context in which Zerfass's model was developed should be taken into account. Utilisation of this model should be evaluated in its own context, by means of asking essentially critical questions like the following: Does the model guide thought development in such a way that a theocentric approach is not undermined by an anthropocentric focus? To what extent are the normative focus and life-changing power of the revelation of God in Scripture addressed in the process of hermeneutical 
interchange? Does a cyclical approach (continually replacing one praxis by a subsequent one) address the reformational task of Practical Theology sufficiently? Does the model's expression of the relationship between Practical Theology and social sciences not compromise the theological quality of Practical Theology? The conclusion arrived in this article is that some essential modifications are needed when utilising Zerfass's model from a reformed context.

\section{Opsomming}

\section{Die aanwending van Rolf Zerfass se handelingswetenskaplike model in prakties-teologiese teorievorming - 'n gereformeerde perspektief}

Rolf Zerfass se handelingswetenskaplike model vir die korrektief op die Christelik-kerklike praksis word dikwels aangewend in prakties-teologiese navorsing aan die NoordwesUniversiteit. Met die eerste oogopslag lyk dit of Zerfass se model 'n ideale raamwerk bied om 'n prakties-teologiese studie deur al die relevante metodologiese fases te stuur. In die genoemde model word klem gelê op die siklus wat nodig is om van 'n problematiese Christelik-kerklike praksis na 'n nuwe praksis te beweeg. 'n Duidelike oorsig word ook gebied op die hermeneutiese wisselwerking tussen teologiese tradisie en operasionele praksis, asook tussen teologie en sosiale wetenskappe. 'n Prakties-teologiese navorser wat sy/haar vertrekpunt neem in 'n gereformeerde benadering behoort hom-/haarself egter te verantwoord ten opsigte van die mate waarin Zerfass se model diensbaar kan wees om te beantwoord aan sy/haar unieke beskouing oor vertrekpunte en doelstellings vir praktiesteologiese teorievorming. Die agtergrond waarteen Zerfass se model ontstaan het, behoort in ag geneem te word. Aansluiting by en gebruik van die model behoort in sy eie konteks beoordeel te word deur wesenlike kritiese vrae soos die volgende te vra: Word die gang van nadenke nie deur die model in 'n rigting gestuur waarin 'n antroposentriese gerigtheid die teosentriese benadering uit fokus kan laat raak nie? In watter mate kom die normatiewe gerigtheid en lewensvernuwende krag van die openbaring van God in die Skrif tot sy reg in hermeneutiese wisselwerking? Kan 'n sikliese benadering (waarin een praksis voortdurend deur 'n nuwe vervang word) die reformatoriese taak van Praktiese Teologie ten volle tot sy reg laat kom? Word die teologiese kwaliteit van Praktiese Teologie nie in gedrang gebring deur die manier waarop die verhouding tussen Praktiese Teologie en die sosiale wetenskappe in die model ingerig word nie? In hierdie artikel word bevind dat enkele aksentverskuiwings en spesifiserings nodig is 
om Zerfass se model in 'n gereformeerde konteks te gebruik en daarby aan te sluit.

\section{Inleiding}

Praktiese Teologie word vandag hoofsaaklik binne 'n handelingswetenskaplike benadering bedryf met as hoofaktiwiteit die verandering en verbetering van die praksis (Pieterse, Greyling \& Janse Van Rensburg, 2004:89; vgl. Kruger \& Venter, 2001:558). In prakties-teologiese metodologie aan die Fakulteit Teologie van die Noordwes-Universiteit word dikwels aangesluit by Rolf Zerfass se handelingswetenskaplike model as korrektief op die Christelikkerklike praksis. Venter (1996:25) interpreteer Zerfass se model in 'n konteks van hermeneutiese wisselwerking wat in die proses van prakties-teologiese teorievorming plaasvind. In prakties-teologiese teorievorming is daar naamlik van twee refleksiedomeine sprake: kommunikatiewe handelinge in die opskrifgestelde openbaring en kommunikatiewe handelinge in die konkrete bediening daarvan in die kerk. In teorievorming word ten opsigte van die eerste refleksiedomein basisteoreties te werk gegaan en ten opsigte van die tweede refleksiedomein praktykteoreties. Terwyl sowel basisteorie as praktykteorie met een werklikheid te doen het, behoort die twee refleksiedomeine tydens die proses van teorievorming in hermeneutiese wisselwerking met mekaar gestel te word (vgl. De Klerk \& Nagel, 2004:127). De Klerk (1999:166) onderskei in sy prakties-teologiese studie oor Skriflesing in die samekoms van die gemeente tussen basisteorie (wat verkry word deur eksegetiese ondersoek en die ondersoek van die kerklike tradisie) en praktykteorie (riglyne waarop Skriflesing as spreke van God, as belewing van God se teenwoordigheid in die samekoms herwaardeer kan word). Die model van Zerfass word ook gebruik as 'n raamwerk om op metateoretiese vlak die resultate en metodologie van relevante dissiplines soos die Psigologie, Sosiologie, Kommunikasiekunde en regswetenskappe in 'n eie teorievorming te integreer (Venter, 2004:431; vgl. Grosskopf \& Lotter, 2003:13). Verder word die model ook as 'n nuttige vertrekpunt gebruik om ontevredenheid met onhoudbare elemente in die huidige praksis van ' $n$ bepaalde kerklike praksis vernuwend te benader. Die model funksioneer in 'n konteks waarin die bestaande praksis en die duidelike spanning of diskrepansies wat daarin bestaan, deur sekere handelinge vernuwe word, sodat 'n nuwe praksis tot stand kan kom (vgl. Grosskopf \& Lotter, 2003:15). 
Die rede waarom Zerfass se model in die metodologiese aanpak van verskeie prakties-teologiese studies ingespan word, is waarskynlik geleë in die raamwerk wat dit bied vir die ondersoek van verskillende vlakke van hermeneutiese wisselwerking tussen teologiese tradisie en huidige situasie, norm en praktyk, die ideale en reële, teologie en ander geesteswetenskappe. Deur hermeneutiese wisselwerking te omskryf en te integreer in teorievorming, word verseker dat basisteorie nie in die lug bly hang nie, praktykteorie ankerloos ronddryf nie en metateorie onverrekend gelaat word nie. Deur van 'n model gebruik te maak, word die verkeer gereël in die eerste abstrahering van praksis en die eerste konkretisering van teorie (vgl. Heyns, 1990:33). Deur die gebruik van die model word verseker dat alle faktore in ag geneem en organies geïntegreer word wanneer daar sprake is van die vervanging van 'n bestaande praksis deur 'n nuwe praksis.

Dit is egter nodig dat die aansluiting by en gebruik van Zerfass se model vanuit 'n gereformeerde perspektief goed verantwoord word. Die agtergrond waarteen Zerfass se model ontwikkel het, behoort nagegaan en 'n aantal kritiese vrae behoort gestel te word ten opsigte van aansluiting by en gebruik van hierdie model. Die belangrikste kritiese vrae wat in hierdie artikel gevra word, is die volgende:

- Word die gang van nadenke nie deur dié model in 'n rigting gestuur waarin 'n antroposentriese gerigtheid die teosentriese benadering uit fokus kan laat raak nie?

- Wat presies word bedoel met hermeneutiese wisselwerking en wat is die aard van wisselwerking soos dit in Zerfass se model ter sprake kom?

- Watter dryfvere laat die handelingswetenskaplike arbeid van Praktiese Teologie opgaan in 'n soort teorievorming wat uitsluitlik gerig is op die vervanging van 'n bestaande praksis met 'n nuwe praksis?

- Watter invloed het Zerfass se beskouing en die manier waarop sy model ingerig word op die verhouding tussen Praktiese Teologie en die sosiale wetenskappe?

Ten einde hierdie kritiese vrae doelmatig te behandel, word die gang van die artikel soos volg ingerig: Die denkklimaat en konteks waarin Zerfass se handelingswetenskaplike model as korrektief op die Christelik-kerklike praksis ontstaan het, word nagegaan. Daarna word die werking van die model uiteengesit met die fokus op die 
kenmerkende wisselwerking wat daarin uitgebeeld word. Die artikel word afgesluit met 'n beoordeling en spesifisering van die wyse waarop vanuit 'n gereformeerde perspektief by die betrokke model aangesluit word.

\section{Die konteks van Zerfass se handelingswetenskaplike model}

In hierdie onderafdeling word hoofsaaklik gefokus op die konteks van Zerfass se handelingswetenskaplike model as korrektief op die Christelik-kerklike praksis. Ook word die invloed van die kritiese rasionalisme op ontwikkelinge in die Praktiese Teologie tydens die sestigerjare van die twintigste eeu nagegaan.

\subsection{Die denkklimaat van die sestigerjare van die 20ste eeu}

Zerfass se handelingswetenskaplike model as korrektief op die Christelik-kerklike praksis ontstaan binne die denkklimaat van die sestigerjare van die twintigste eeu en die denkontwikkeling wat in hierdie tydsgewrig in prakties-teologiese kringe plaasvind. Tot en met hierdie tyd is Praktiese Teologie - in navolging van Schleiermacher - hoofsaaklik beoefen as 'n "toepassing" van teologiese waarheid. Die Barthiaanse teologie het hierdie opvatting sterk gehandhaaf (vgl. Dingemans, 1989:193). Die invloed van Barth se Woord-teologie laat Praktiese Teologie opgaan in 'n toegepaste Dogmatiek of praktiese Pneumatologie (Heitink, 1999:112). Bohren se prakties-teologiese denke word deur Heitink (1999:112) omskryf as 'n tipiese voortsetting van die Barthiaanse "teologisering" van Praktiese Teologie. Die empiriese werklikheid word geteologiseer deurdat God prakties word in die sin dat Hy aanskoulik (schön) word (Bohren, 1975:14). Weens hierdie teologiserende benadering word prakties-teologiese teorievorming sterk gekanaliseer in 'n eenrigtingverkeer vanaf openbaring na konkrete situasie en vanaf teorie na praktyk.

\section{2 'n Fokusverskuiwing na die konkreet-lewende mens en sy situasie}

In die denkklimaat van die sestigerjare vind 'n fokusverskuiwing plaas na die konkreet-lewende mens en sy situasie (Jonker, 1983:18). Die kritiese ingesteldheid van die mens tree op die voorgrond. Die inrigting van kerklike praktyke en tradisies wat jare lank as vanselfsprekend beskou en kritiekloos aanvaar is, word aan nuwe ondersoek onderwerp. Die oue en tradisionele word verdag, terwyl die nuwe en die vreemde aandag trek. Die hedendaagse 
mens bied homself aan vanuit eie visie en eie leefervaringe. Vrae word gevra oor die relevansie van die Christelike geloof vir die hede. Daar word gevra in hoe ' $n$ mate huidige kerklike praktyke belas is deur kultuurgebonde voorstellings uit die oudheid. Op allerlei wyse word die kerk uitgedaag. Vrae wat niemand voorheen sou waag om te vra nie, word gestel (Jonker, 1983:20). In die Praktiese Teologie word gevolglik indringend oor die verhouding tussen teorie en praktyk nagedink. In hierdie nadenke oor die verhouding tussen teorie en praktyk word daar in reaksie teen die Barthiaanse benadering (eenrigtingverkeer vanaf teorie na praktyk) 'n nuwe swaartepunt gelê op die kritiese vrae wat die konkrete mens vanuit sy leefervaring aan die teorie kan stel.

\subsection{Bastian se teologie van vrae}

Bastian ontwerp 'n teologie van vrae waarin hy sy weerstand verwoord teen 'n teologie wat onmiddellik klaargemaakte antwoorde op alle probleme bied en wat nie rekening hou met die vrae wat in die gemoed van die gelowige kan opkom nie (Heitink, 1999:112). Onder druk van maatskaplike kritiek gedurende die sestigerjare moes gereageer, gereformeer, verander word op verskeie vlakke van die kerklike lewe (vgl. Zerfass, 1974:164). Bastian trek raaklyne tussen die histories-kritiese metode wat in eksegetiese kringe gebruik is en die metodologie van Praktiese Teologie: net soos die histories-kritiese metode gelei het tot 'n ontmitologisering van die Bybelse teks, lei 'n empiriese benadering tot 'n ontmitologisering van die praksis. In 'n empiriese benadering konsentreer Praktiese Teologie minder op vrae wat te doen het met die spekulatiewe (die wat- en waarom-vrae), maar meer op vrae oor hoe die praksis behoort te werk. Dan eers word praksis wat dit teologies veronderstel is om te wees: "zur Einspruchintstanz gegen selbstzufriedene Spekulation" (Bastian, 1968:32). Hiermee vra Bastian aandag vir die eie wêreld en die eie vrae van mense as onderdeel van teologiese nadenke naas besinning oor die "Woord". Solank die teologie van die Woord (Barth: die dialektiek tussen God se Woord en mensewoorde) op spekulatiewe wyse die Praktiese Teologie die woord in die mond lê, word die tegniese wêreld óf geïgnoreer óf gedemoniseer (vgl. Dingemans, 1989:194). Bastian sien 'n drievoudige taak vir die Praktiese Teologie: 'n kritiese taak met betrekking tot kerklike tradisie, 'n empiriese taak met betrekking tot die manier waarop die kerk in die hede optree, en 'n prospektiewe taak met betrekking tot toekomsbeplanning:

Sie ist kritisch orientiert, soweit sie Traditionen wahrnimmt; sie ist empirisch orientiert, soweit sie Handlungskomplexe der 
Gegenwart analysiert; sie ist prospektiv plannend, soweit sie Zukünftiges bedenkt (Bastian, 1968:41).

Sonder nuwe vergestalting (Neugestaltung) en herinterpretasie (Neuinterpretation) van die teologiese oorlewering, sterf kerklike rede 'n kerugmatiese dood (Bastian, 1965:11). In die uitvoer van hierdie taak is die Praktiese Teologie sowel "kirchliche Oppositionswissenschaft" as "kirchliche Stabilisationswissenschaft" (Bastian, 1968:45). As voorbeeld van die konsekwensies van Bastian se denke kan verwys word na die tradisionele standpunt (diep ingebed in die kerklike tradisie) dat prediking die verkondiging van die Woord van God is en daarom voordelig moet wees. Vir die kritiese vraagsteller is dit vanuit sy eie ervaring duidelik dat hierdie tradisionele standpunt nie geharmonieer kan word met die resultate wat deur empiriese navorsing verkry word nie. Empiriese navorsing toon dat die realiteit van 'n swak kommunikatiewe praksis die prediking uiters oneffektief maak. Sonder nuwe vergestalting en herinterpretasie sal hierdie tradisie 'n kerugmatiese dood sterf.

\subsection{Die invloed van die kritiese rasionalisme}

Bastian se benadering word volgens Heitink (1999:127) gegrond in die kritiese rasionalisme van Karl Popper; 'n benadering wat sy vertrekpunt neem in die soeke na waarheid en fokus op die falsifisering van stellings (vgl. Bastian, 1968:49). Popper gaan in sy denke uit van die veronderstelling dat die verifikasiebeginsel (soos omskryf deur die logiese positivisme) onvoldoende is. Wanneer by wyse van falsifisering 'n teenvoorbeeld (counter-example) aangedui kan word, kan die logiese, universele aanvaarbaarheid van 'n aanname in gedrang kom (Louw, 2003:40). Vir Popper is dit wat as kennis aangebied word, niks anders as teorie wat nog nie verkeerd bewys is nie. Teorieë moet beoordeel word volgens die waarskynlikheid van hulle hipotese (Heintink, 1999:151). Popper sien die ervaringswetenskappe as teoriesisteme. Die teorie is die net wat uitgegooi word om die wêreld op te vang deur dit te rasionaliseer, te verklaar en te beheers. Die praktiese teoloog staan as homo ludens (spelende mens) in die Regelkreis tussen die praksis van homo faber (die tegniese mens) en die teologiese besinning van homo sapiens (die wyse mens) in die rol van spelstrateeg wat verantwoordelik is vir modelle waarin die struktuur en funksie van kerklike handelinge uitgedruk word (Bastian, 1968:54).

Die agtergrond van die denkklimaat van die sestigerjare van die twintigste eeu behoort in gedagte gehou word wanneer Zerfass se 
model verklaar word. Ook moet die wyse waarop in die eie denke aangesluit word by hierdie model, verantwoord word. Wanneer die model in punt 4 van hierdie artikel uiteengesit en in punt 5 beoordeel word, behoort - in die lig van bostaande bespreking - opgelet te word na die volgende: Die opvallende manier waarop daar in die inrigting van die model nie alleen sprake is van verkeer wat gereël word vanuit teorie na die praksis nie, maar ook vanuit praksis na teorie. ' $n$ Teologiese benadering wat nie meer die verkeersvloei tussen teorie en praktyk as eenrigtingverkeer inrig nie, maar die dimensie van wisselwerking inbou, behoort homself te verantwoord oor die manier waarop wisselwerking ingerig word. Die volgende vrae moet in hierdie opsig gevra word:

- Ontkrag die konsep van wisselwerking waarin die interpretasie van die Woord in wisselwerking met die interpretasie van die konkrete situasie van die kerk geplaas word, nie die sterk stroom van die vrymagtige Woord wat roep om lewensvernuwing volgens die wil van God nie?

- Hoe word seker gemaak dat die Neugestaltung wat deur wisselwerking ontstaan het, nie die skepping van die mens met sy interpretasievermoë is nie?

\section{Die verhouding tussen Praktiese Teologie en die sosiale wetenskappe}

\subsection{Die invloed van die sosiale wetenskappe}

In hierdie onderafdeling word ingegaan op die invloed wat die sosiale wetenskappe uitgeoefen het op die ontwikkelingsgeskiedenis van Praktiese Teologie. In die vroeëre jare van die ontwikkelingsgeskiedenis van Praktiese Teologie was die sogenaamde theologica practica ingerig as 'n praktiese toepassing van dogmatiese teologie en het dit opgegaan in die deurgee van praktiese riglyne vir bedienaars van die Woord. Met die opkoms van die sosiale wetenskappe aan universiteitsfakulteite het Praktiese Teologie ook 'n eie gesig begin kry wat - in aansluiting by metodologieë van die sosiale wetenskappe - sy eie handelingswetenskaplike vakgebied begin ontwikkel het (vgl. Ballard, 2001:6). Vroeër was teologie die leidende wetenskap en was sosiale wetenskappe beskou as "hulpwetenskappe" - blote diensknegte by die toepassing van teologiese waarhede in die praktyk. Mettertyd het die sosiale wetenskappe hulle eie navorsingsmetodes begin ontwikkel wat verreikende gevolge sou hê vir die manier waarop teologie die konkrete handelingswerklikheid van die kerk en 
empiriese godsdienstige verskynsels metodologies sou ondersoek. Aanvanklik het uit die pastorale praktyk geblyk dat daar op 'n vrugbare wyse aangesluit kan word by die metodes en resultate van die Psigologie, Psigiatrie en Psigoterapie. Na die Tweede Wêreldoorlog is ook toenemend aansluiting gevind by die Sosiologie in die analise van die samelewing en die kerk as samelewingsverskynsels. Die Pedagogiek en Didaktiek as dissiplines het 'n rol begin speel in die teorievorming rondom geloofsopvoeding en kategese. Ook is kennis geneem van die resultate van die Kommunikasiekunde en Retoriek in homiletiese teorievorming (vgl. Dingemans, 1996:36 e.v.). Hierdie verhouding met die sosiale wetenskappe het daartoe bygedra dat Praktiese Teologie toenemend die aard van 'n interdissiplinêre wetenskap verkry het.

\subsection{Praktiese Teologie as integrasiewetenskap}

Met die aansluiting by en gebruik maak van die nuut ontwikkelde navorsingsmetodes van die sosiale wetenskappe, is opnuut kennis geneem van C.I. Nitsch ('n leerling van Schleiermacher) se lang vergete teorie vir die kerklike lewe. Nitsch stel 'n drieledige metodologie vir Praktiese Teologie voor, naamlik:

- die empiriese en historiese metode (Praktiese Teologie help om 'n gegewe toestand in die kerklike lewe te omskryf);

- die logiese metode, waarin die vraag na die grond van kerklike handelinge gevra word en

- die tegniese of regulatiewe metode, waarin aanwysings gegee word vir die praksis.

In die lig van die metodologie wat in die sosiale wetenskappe gebruik word, is al hoe meer tot die konsensus gekom dat Praktiese Teologie ' $n$ interdissiplinêre wetenskap is wat hom besig hou met drie aandagsvelde:

- Prakties-teologiese ondersoek begin met 'n grondige analise van die praksis;

- in 'n tweede rondte van die ondersoek vind nadenke oor norme vir handelinge plaas; en

- ten slotte probeer Praktiese Teologie aanwysings gee om die praksis te verbeter.

Om sodanige program uit te voer, behoort gebruik gemaak te word van die resultate en metodes van die sosiale wetenskappe: vir 
Kategetiek behoort van die Pedagogiek en Didaktiek gebruik gemaak te word; vir Pastoraat van die Psigologie; vir Homiletiek van die Retorika en Kommunikasieteorie; vir prakties-teologiese Ekklesiologie van die Sosiologie en Sosiale Psigologie. Praktiese Teologie staan op hierdie wyse as 'n soort "integrasiewetenskap" (Dingemans, 1989:200) tussen ander teologiese dissiplines aan die een kant, en die sosiale wetenskappe aan die ander kant.

\subsection{Interdissiplinêre aansluiting by empiriese en hermeneu- tiese ondersoekmetodes}

In die interdissiplinêre aansluiting by die navorsingsmetodes van die sosiale wetenskappe het prakties-teologiese wetenskapsbeoefening veral kennis geneem van die empiriese ondersoekmetode en die hermeneutiese ondersoekmetode.

- In die empiriese ondersoekmetode word 'n samelewingsverskynsel ondersoek deur inligting in te samel, vergelykings te tref, statistieke op te stel en patroonmatighede vas te stel. Die impak wat verskille in klas, ras, beroep, geslag, ouderdom, gesinstruktuur of woonplek op 'n bepaalde verskynsel het, kan byvoorbeeld statisties akkuraat bereken word. In die suiwer empiriese ondersoekmetode word gewoonlik kwantitatief te werk gegaan.

- In die hermeneutiese ondersoekmetode word egter meer kwalitatief te werk gegaan. Daar word in 'n groter mate gefokus op die konnotasie wat mense aan sekere samelewingsverskynsels heg en die interpretatiewe netwerk uit die verlede wat bepaal met watter voorbehoude daar opgetree of gereageer word (Browning, 1996:87).

\subsection{Aansluiting by die navorsingsmetodes van die sosiale wetenskappe}

Verskille in die maniere waarop of die mate waarin aansluiting gevind kan word by die navorsingsmetodes van die sosiale wetenskappe, het grootliks daartoe aanleiding gegee dat praktiesteologiese wetenskapsbeoefening in verskillende strominge verdeel het. Drie van die mees opvallende van hierdie strominge kom vervolgens kortliks aan die orde.

- Die normatief-deduktiewe stroming: die normatiewe openbaringsbron van die Skrif het die eerste en die laaste sê in teorievorming 
terwyl kennis geneem word van die resultate van die sosiale wetenskappe as "hulpwetenskappe";

- die empiries-analitiese stroming wat in die besonder aansluit by die empiriese navorsingsmetode van die sosiale wetenskappe; en

- die hermeneuties-bemiddelende stroming wat grootliks aansluit by die hermeneutiese navorsingsmetode van die sosiale wetenskappe (vgl. Heitink, 1999:171 e.v.).

\subsubsection{Die normatief-deduktiewe stroming}

Die normatiewe- deduktiewe stroming in prakties-teologiese wetenskapsbeoefening kom duidelik na vore in die benadering van die dialektiese teologie. Menslike vermoë en handelinge (en die gebrek aan geloof wat daarin te voorskyn kom) word ontbloot deur die gebeurlikheid van God se Woord. Die enigste vorm van bemiddeling tussen teorie en praksis lê in die sterk eenrigtingstroom van verkondiging, soos dit byvoorbeeld in Thurneysen se pastorale benadering na vore kom (vgl. Heitink, 1999:171). Bohren (1975:14) waak teen aansluiting by 'n suiwer sosiaal-wetenskaplike benadering aangesien hierdie benadering daartoe kan lei dat daar op 'n te eng wyse na die werklikheid van die kerklike praksis gekyk word. Wanneer gekonsentreer word op die sigbare met sy begrensde moontlikhede, kan God verhinder word om "prakties" te word in die werklikheid van kerklike praksis. Jonker (1983:14) hou daarmee rekening dat die kerk in 'n samelewing verkeer wat kultureel voortdurend ontwikkel, maar hy vrees dat die neiging om Praktiese Teologie in die rigting van 'n teorie van aksie te ontwikkel, teologiese reduksie tot gevolg kan hê. Hy pleit vir 'n benadering wat op ' $n$ deduktiewe manier begin by die teologie en die geheimenis wat onlosmaaklik daarmee gepaardgaan, terwyl bydraes van die sosiale wetenskappe op hulpwetenskaplike vlak geïntegreer word in teologiese lig en met teologiese verantwoording. Teorievorming sonder veldondersoek gaan op in abstraksies. Veldondersoek sonder prakties-teologiese teorievorming kan egter maklik lei tot 'n rondval tussen die massa onverwerkte feite. Jonker (1968:23) pleit vir 'n teologiese radikalisering van die diakoniologiese vakke. Hierdie teologiese radikalisering behoort egter nie op 'n relativering van die konkrete diens van die kerk uit te loop nie.

Van die diakoniologiese vakke mag verwag word om die kerk te dien met soveel moontlik kennis oor die mens, sy wêreld, sy psige en sy taal. Die diakoniologiese vakke moet voortdurend op hoogte bly van 
dit wat van die mens gesê word in die sosiale wetenskappe. In hierdie proses moet egter versigtig daarop gelet word dat Woord van God nie onderwerp word aan die maatstawwe van die hedendaagse samelewing en mens nie. Dit is vir die kerk van groot belang om die hedendaagse mens in sy situasie te verstaan, want die kerk is geroep om die evangelie in die taal van die mens aan hom oor te dra. Dit mag egter nooit beteken dat die mens van vandag vir die kerk die kriterium word van wat wel en wat nie verkondig of gedoen mag word nie. Die amptelike vakke moet daarvan bewus bly dat die primêre interesse nie die empiriese gegewens van die mens en sy wêreld kan wees nie, maar wel die openbaring van God in Jesus Christus.

Vir Heitink (1999:171) loop hierdie normatief-deduktiewe stroming in prakties-teologiese wetenskapsbeoefening die gevaar dat dit kan bly vassteek in eksegese en dogmatiese formules, sonder om ooit werklik uit te kom by 'n hermeneutiese en empiriese analise van die verhouding tussen teorie en praksis.

\subsubsection{Die empiries-analitiese stroming}

In die empiries-analitiese stroming in prakties-teologiese wetenskapsbeoefening word sterk aansluiting gevind by die empiriese navorsingsmetode van die sosiale wetenskappe. Die navorser sien homself eerder as 'n objektiewe waarnemer as 'n deelnemer (vgl. Dingemans, 1996:42). Hierdie stroming ontwikkel sterk op die spoor van Bastian wat in sy aansluiting by die kritiese rasionalisme pleit vir die objektiewe empiriese studiemetode. Heitink (1999:173) wys daarop hoe hierdie stroming metodologies die empiriese siklus volg soos dit ontwikkel is deur A.D. de Groot: Navorsing word naamlik ingerig as ' $n$ empiriese toetsing van hipoteses, wat gewoonlik uit 'n bestaande teorie afgelei kan word. Die empiriese navorsing gaan deur die volle empiriese siklus van waarneming, induksie, deduksie, toetsing en evaluering (vgl. Heitink, 1999:231). Die empiriese navorsing word onderneem met die doel om helderheid te gee of sekere verhoudings, wat op teoretiese gronde veronderstel is om gereed te wees, in die empiriese werklikheid wel geïdentifiseer kan word. Toetse kan ook aangelê word om die werklike effek van sekere handelinge op mense vas te stel. Hierdie navorsingsmetode kan in die denkraamwerk van die kritiese rasionalisme opgaan in die falsifisering van spesifieke hipoteses. In hierdie benadering word op 'n intradissiplinêre wyse volledig aangesluit by die sosiaalwetenskaplike navorsingsmetode in die hantering van teologiese probleme. 


\subsubsection{Die hermeneuties-bemiddelende stroming}

In die hermeneuties-bemiddelende stroming in prakties-teologiese wetenskapsbeoefening word aangesluit by die hermeneutiese navorsingsmetode wat in die kringe van die sosiale wetenskappe ontwikkel is. In 'n hermeneutiese benadering word nie alleen die gedrag van mense nie, maar ook die rede waarom hulle op 'n sekere manier optree, nagespeur. As integrasiewetenskap het Praktiese Teologie die bemiddelende taak om hermeneutiese wisselwerking tussen teorie en praksis, norm en werklikheid op 'n integrale en organiese wyse te laat plaasvind. Dingemans (1996:45) huldig die mening dat Praktiese Teologie deur hierdie stroming as 'n hermeneutiese interpretasiewetenskap toegepas word. Sy invalshoek vir die omskrywing van hierdie stroming is geleë in sommige teoloë se besware teen 'n benadering waarin te veel gefokus word op die "uiterlike" handelinge van mense. Wanneer 'n benadering te veel fokus op die empiriese, raak dit bloot deskriptief-analities van aard met 'n eensydige gebruik van die kwantitatiewe metode. Daar behoort rekening daarmee gehou te word dat agter alle menslike dade (handelinge) onderliggende gedagtes, voorstellings en interpretasies geleë is. "Handelinge" kan nie losgemaak word van die intensies wat daaragter sit nie. As 'n praktiese teoloog religieuse praksis wil verander of wil verbeter, het dit geen sin om alleen die "handelinge" of die "gedrag" van mense sonder die onderliggende intensies na te speur nie. Daarom behoort 'n weg gesoek te word in die rigting van 'n hermeneutiese wetenskapsopvatting.

In hierdie hermeneutiese benadering word gebruik gemaak van sosiaal-wetenskaplike metodes wat grotendeels ontleen is aan die taalwetenskappe. Dit is veral in aansluiting by taalteorieë soos dié van Gadamer en Ricoeur dat die werklikheid nie as 'n blote vasstaande of selfs objektiewe gegewenheid (empirie) verstaan word nie, maar as 'n menslike konstruksie of interpretasie wat ontstaan in die wisselwerking tussen visie en realiteit. Ons sien dinge en doen dinge op grond van 'n "blik", 'n "vooroordeel", 'n "paradigma" of 'n "interpretasienetwerk", waarbinne die werklikheid verstaan, gevorm, getransformeer en verander word (Browning, 1996:81; vgl. Louw, 2003:40). Ricoeur lees die hele werklikheid as teks: as "talige" gebeurtenisse en handelinge. ("Teks" kom van die Latynse textum $=$ weefsel.)

In die ondersoek vanuit ' $n$ hermeneutiese benaderingswyse word nie gefokus op harde en teoreties kontroleerbare statistieskwalifiseerbare gegewens oor die werklikheid (objektiwiteit) nie, maar eerder op die samehang van betekenisse, interpretasies en 
kwalifikasies van mense en groepe soos dit aangetref word in dokumente, verhale, handelingswyses en biografieë van deelnemers. Hierdie kwalifikasies van mense en groepe vorm 'n simboliese heelal waarin menslike handelinge deur sosiale of kulturele verbeelding beïnvloed word (Dingemans, 1996:47; vgl. Dreyer, 2002:5). In 'n gesprek met Kearney (1984:23) het Ricoeur die volgende te sê oor taal en verwysing:

There can be no praxis which is not already symbolically structured in some way. Human action is always figured in signs, interpreted in terms of cultural traditions and norms ...The referent of narration, namely human action, is never raw or immediate reality but an action which has been symbolized and resymbolized over and over again.

Teen die agtergrond van gelowige handelinge staan voortdurend die teks van die Bybel en die tekste van die Christelike tradisie: belydenisskrifte, teologiese verklarings, Bybelkommentare, kerkordes, reglemente en ander dokumente van gesamentlike ooreenkoms. Die praktiese handelinge van Christene word in prinsipe aangevoer deur die evangelie van Jesus Christus, soos dit oorgelewer is via tekste van die verlede wat vir die hede geïnterpreteer word (Dingemans, 1996:48). Teologie ontstaan uit 'n interaksie op die kruispunt van tradisie en konteks, waarin die tradisie (inklusief Bybelse bronne) gelees en geïnterpreteer word. Teologie is ' $n$ interpretasie van tradisie in wisselwerking met die konteks. Die hermeneutiese benadering is dus daarvan oortuig dat ons "oordeel" of ons "vooroordeel" 'n groot rol speel by die interpretasie van die Skrif (Dingemans, 1996:49).

Dit sou moeilik wees om die benadering van Zerfass - soos dit uit sy model blyk - vierkantig slegs in een van bogenoemde strominge in te pas. In die bespreking van die model onder hoofpunt 4 behoort opgelet te word in hoe 'n mate elemente van sowel die empiriesanalitiese stroming (die verifikasie en falsifisering van hipoteses) as die hermeneuties-bemiddelende stroming (die interpretasie van die tradisie in wisselwerking met die konteks) ter sprake kom. In die mate waartoe by Zerfass se model aangesluit kan word, behoort ' $n$ eie beskouing oor die verhouding tussen Praktiese Teologie en die sosiale wetenskappe goed omlyn en verantwoord te word. Wanneer Praktiese Teologie as 'n "integrasiewetenskap" of hermeneutiese "interpretasiewetenskap" getipeer word, behoort baie duidelik gemaak te word wat onder integrasie en interpretasie verstaan word. Dit sou nodig wees om 'n eie beskouing oor die verhouding tussen Praktiese Teologie en die sosiale wetenskappe duidelik te 
omlyn, sodat die teologiese kwaliteit van Praktiese Teologie aan die een kant nie in gedrang kom nie, en die bydrae en insigte van die sosiale wetenskappe aan die ander kant nie geïgnoreer word nie. Van der Ven (1990:104 e.v.) onderskei die volgende moontlikhede vir die inrigting van die verhouding tussen Praktiese Teologie en die sosiale wetenskappe:

- 'n Monodissiplinêre benadering waarin die Bybel of die leer van die kerk regstreeks aangewend word vir die praktyk van religieuse handelinge;

- 'n multidissiplinêre benadering waarin teologie en sosiale wetenskappe langs mekaar staan - teologie spreek die laaste woord, terwyl kennis geneem word van die bydraes van die sosiale wetenskappe as hulpwetenskaplik van aard;

- 'n interdissiplinêre benadering waarin teologie en sosiale wetenskappe na mekaar luister en met mekaar in gesprek tree as verteenwoordigers van verskillende invalshoeke op dieselfde sosiale realiteit. Die kerk kan byvoorbeeld bestudeer word as werksterrein van die Gees, maar ook as handelingsterrein van mense.

- Die verskillende invalshoeke kan mekaar bevrug sonder dat een heers oor die ander deur ' $n$ intradissiplinêre benadering te volg waarin sosiaal-wetenskaplike metodes deur teoloë toegepas word met 'n tipiese teologiese vraagstelling. Volgens hierdie benadering word veronderstel dat teoloë die praktiese metodes van sosiale wetenskappe moet leer, presies soos Ou- en NuweTestamentici die praktiese metodes van die literêre en historieskritiese ondersoek moes leer (vgl. Dingemans, 1996:61).

Noudat die konteks waarbinne Zerfass se handelingswetenskaplike model ontstaan het as korrektief op die Christelik-kerklike praksis, kortliks uiteengesit is, kan daartoe oorgegaan word om die werking van die model te verduidelik.

\section{Die werking van Zerfass se model as korrektief op die Christelik-kerklike praksis}

Zerfass (1974:166) omskryf sy model as: "ein handlungswissenschaftliches Modell der Korrektur christlich-kirchlicher Praxis". Hy werk met die definisie van 'n model as "eine Anordnung von Zeichen und Verknüpfungsregeln, die einer Anzahl relevanter Merkmale in einem Realgebilde, in tätsachlichen Vorgängen entsprechen sollen". In hierdie sin word die grondstruktuur van 'n korrigerende ingrype in 
die handelingsfeer van die Christelik-kerklike praksis in Zerfass se model op ideaal-tipiese wyse daargestel.

\subsection{Oorsig oor die werking van Zerfass se model as korrektief}

'n Oorsig oor die werking van Zerfass se handelingswetenskaplike model as korrektief op die Christelik-kerklike praksis kan aan die hand van die volgende illustrasie met verduidelikende aantekeninge verkry word:

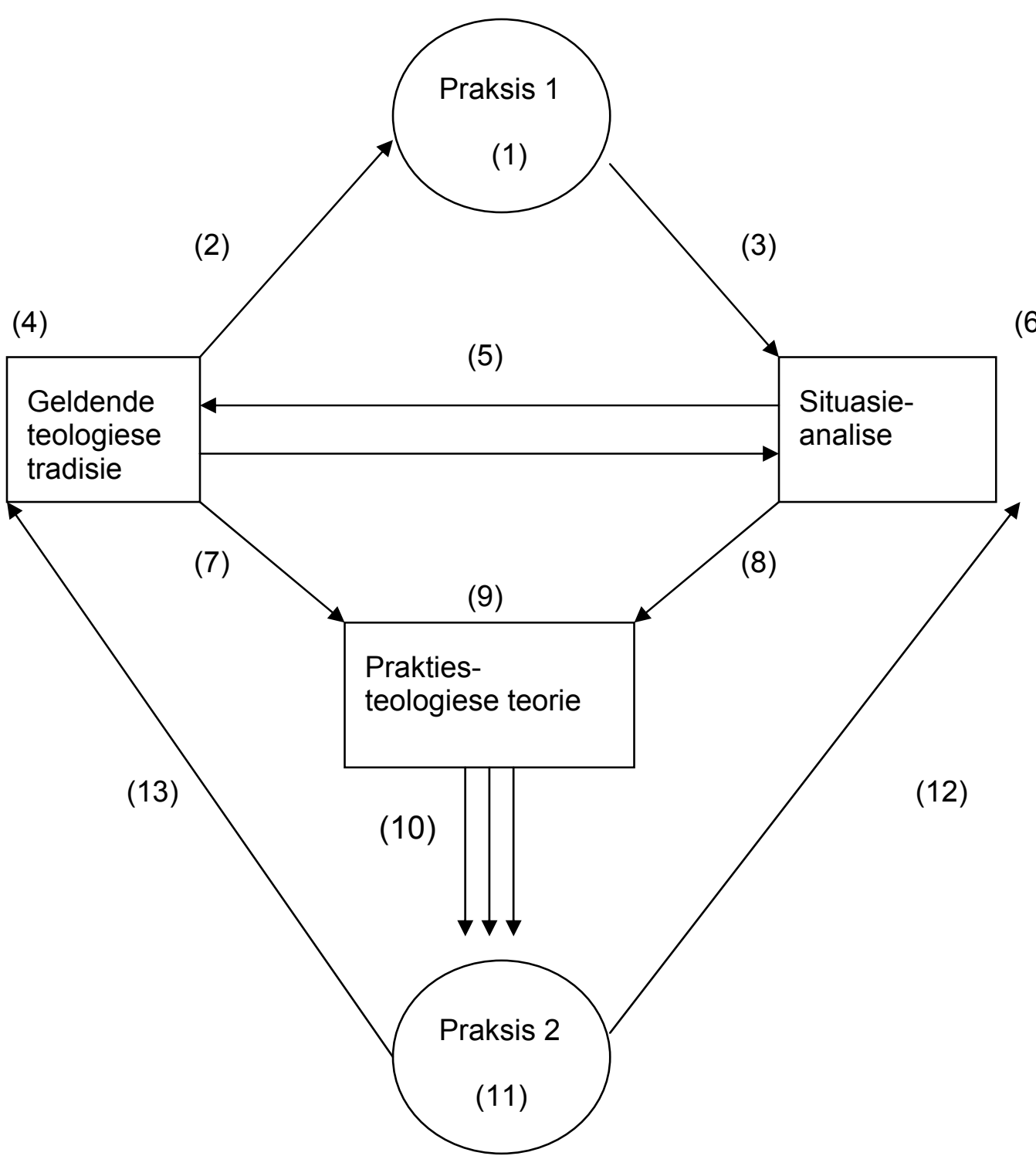

- Die konkrete en ekklesiologiese optrede (Praksis 1)

Die uitgangspunt van 'n handelingswetenskaplik georiënteerde proses van nadenke is per definisie die konkrete Christelike en 
ekklesiologiese optrede. Hierdie praksis kom dikwels in die gestalte van ontoereikendheid na vore. 'n Situasie waarin die getal erediensbywoners afneem, getuig van 'n krisis. Sodanige situasie word gekenmerk deur 'n spanningsvolle aard. Handelingsdruk word geplaas op die situasie ("Daar moet iets gebeur!"). Hierdie handelingsdruk roep op tot 'n bereidheid om na te dink. Oor die situasie moet nagedink word met die doel om vas te stel wat die beste is om hierdie situasie ten goede te verander.

\section{- Reaksie van die teologiese tradisie (vgl. pyltjie 2)}

Die eerste reaksie wat sodanige spanning in die praksisveld van die kerklik-maatskaplike situasie oproep, kom uit die geledere van die heersende teologiese tradisie (4). Die invloed van die geldende teologiese tradisie lê op veelvuldige maniere opgesluit in onbewuste, geïnternaliseerde verhoudingspatrone, denkmodelle en norme vir handelinge wat in dissiplines soos Dogmatiek en Kerkreg neerslag gevind het. Verteenwoordigers van die teologiese tradisie reageer op veranderinge in die handelingsveld deur dit wat as norme beskou word, as geldend voor te hou. 'n Blote herbevestiging van oorleweringaansprake is dikwels blind vir die noodsaak tot verandering of vernuwing en kan konflikversterkend werk.

\section{- Navorsingsprosedure vir 'n situasie-analise (vgl. pyltjie 3)}

Hier kom die navorsingsprosedure (met die gebruikmaking van geldige meetinstrumente uit die sosiale wetenskappe) ter sprake wat nodig is om tot 'n situasie-analise van die empirie te kom (6).

\section{- Wisselwerking tussen teologiese tradisie en die geanaliseerde situasie (vgl. pyltjie 5)}

Die wisselwerking tussen teologiese tradisie en die konkrete, geanaliseerde situasie kom hier ter sprake. Hierdie wisselwerking word dikwels gekenmerk deur die spanning tussen hoe die konkrete situasie veronderstel is om te lyk (Sollbestand) en hoe dit in werklikheid lyk (Istbestand). Inligting wat deur die situasie-analise verkry word, kan op sigself niks vermag nie en het geen intrinsieke handelingsaanwysings nie, maar moet ten opsigte van die implikasies daarvan eers getoets word aan en gekonfronteer word met die gesag (geldigheid) van oorleweringsaansprake uit die kerklike tradisie. Hierdie wisselwerking tussen teologiese tradisie en geanaliseerde situasie verseker dat die uiteindelike handelingsmodel nie bloot opgaan in verandering ter wille van verandering weens druk wat op die situasie geplaas is nie. Met die Christelike 
oorlewering as impuls word verseker dat kritiese ingrype in die handelingsveld konstruktief en met diepgang plaasvind.

\section{- Invloed van die teologiese tradisie en die situasie-analise (vgl. pyltjie 7 en 8)}

Die invloed wat die teologiese tradisie en die analise van die huidige situasie uitoefen op die ontwikkeling van 'n nuwe prakties-teologiese teorie (9) word hier uitgebeeld. Die spanning tussen hoe die konkrete situasie veronderstel is om te lyk (Sollbestand) en hoe dit in werklikheid lyk (Istbestand), vind neerslag in 'n besef dat iets gedoen moet word om die situasie te verbeter. 'n Teorie word ontwikkel oor wat gedoen moet word om die situasie te verbeter. In 'n prakties-teologiese teorie word die geldigheidsbasis uiteengesit waaruit handelingsimpulse vir die daarstel van 'n nuwe praksis organies kan voortvloei.

\section{- Handelingsimpuls in die daarstel van 'n nuwe praksis (vgl. pyltjie 10)}

Die handelingsimpuls van (9) in die daarstel van 'n nuwe praksis (11) kom hier ter sprake. Die prakties-teologiese teorie dien as impuls vir gefokusde optrede in die handelingswerklikheid van 'n nuwe praksis. Hierdie handelingsimpuls is sowel teologies as sosiaal-wetenskaplik verantwoord, aangesien die spanningsveld tussen die oorleweringsaansprake (Sollbestand) en die situasieanalise (Istbestand) op 'n konvergerende wyse hanteer is. Die praksis word deur die handelingsimpuls in die gewenste rigting gestuur.

\section{- Die beoordeling van die nuwe praksis (vgl. pyltjies 12 \& 13)}

Hier word aangedui hoe die beoordeling van die nuwe praksis in die lig van sowel die teologiese tradisie as die analise van die konkrete situasie plaasvind. Deur opvolgondersoek (12) word opnuut 'n nuwe situasie-analise gedoen en die nuwe situasie word met die vorige vergelyk. Terugherleiding na situasie-analise kan tot 'n meer presiese omlyning van die teoretiese raamwerk (9) lei en opnuut weer lei tot nuwe handelingsaanwysings (10). Aan die ander kant behoort 'n nuwe praksis ook by te dra tot 'n verdieping in die verstaan van hoe teologiese oorlewering werk (13), omdat 'n nuwe praksis verteenwoordigend is van 'n nuwe horison waarin die aansprake van die teologiese oorlewering toegepas is. 'n Beter begrip van hoe teologiese oorlewering werk, lei op sy beurt weer oor die herleistasie van 'n verbeterde handelingsteorie (9) tot nader gespesifiseerde handelingsmodelle (10) en daarmee tot 'n "beter" 
praksis (11) (Zerfass, 1974:167 e.v.; vgl. Dingemans, 1989:202; Heitink, 1999:113; Heyns, 1990:36).

Noudat 'n oorsig oor die werking van Zerfass se model verkry is, kan gefokus word op die wese van die proses wat in die model omskryf word; die vertikale en horisontale dimensies wat in die model ter sprake kom en die wesensbestemming wat vir Praktiese Teologie in die parameters van die model vasgestel word. Vir hierdie doeleindes word Zerfass self aan die woord gestel (4.2). Daarna word enkele waarnemings oor die werking en implikasies van die model deur die skrywer van hierdie artikel gemaak (4.3).

\subsection{Funksioneringsaspekte van Zerfass se model en Praktiese Teologie se bestemming}

In hierdie afdeling word die kernaspekte waarvolgens Zerfass se handelingswetenskaplike model funksioneer, behandel asook die wesensbestemming vir Praktiese Teologie wat daaruit voortvloei. Die hartklop van die model lê volgens Zerfass (1974:169) in die driehoek wat in die middel van die model opgesluit is en wat opgebou is uit die volgende pylers: geldende oorlewering (4), geanaliseerde werklikheidsituasie (6) en handelingsimpuls (10). Hierdie driehoek dui op die verhouding tussen die samestellende elemente wat 'n rol speel in die proses waarop die korrektief op die kerklike praksis funksioneer. Hierdie drie faktore loop uit op die moment van teoriebou (9). Die faktore word uiteindelik tot ' $n$ kringloop (Regelkreis) uitgebou, in soverre duidelik gemaak word dat ook die nuwe praksis kritiek en kontrole benodig (12). Ook ontsluit dit nuwe hermeneutiese toegange tot die verstaan van die kerklike tradisie (13) (Zerfass, 1974:169).

Zerfass (1974:170) onderskei 'n vertikale en 'n horisontale dimensie in die werking van sy model.

- In die vertikale aspek van die model is sowel die dimensie van tyd (die teenswoordige en toekomstige as spanningsbeweging tussen Praksis 1 en Praksis 2), as die teorie-praksisprobleem (Praksis 1-Teorie-Praksis 2) en ook die bepaalde konsep van konflikbestuur ter sprake.

- In die horisontale dimensie bring die model spanning tussen geesteswetenskaplike en empiriese metodes na vore. In sowel die vertikale as die horisontale dimensies is daar sprake van spanningsbewegings wat by wyse van wisselwerking hanteer word. 
Vir Zerfass lê die funksiebestemming van Praktiese Teologie op 'n drieledige vlak. Praktiese Teologie moet naamlik die

- kerklike oorleweringe as kritiese potensiaal in die stryd om die teenswoordige en toekomstige invoer;

- die probleme van die teenswoordige situasie ernstig neem, teologies identifiseer en as opgawe aan die kerklike oorlewering bemiddel;

- impulse tot konstruktiewe veranderinge vir die kerklike praksis in die realiseringsfase daarvan krities begelei.

Al drie hierdie momente kan onder die trefwoord "reformasie" saamgebundel word as die tema van Praktiese Teologie (Zerfass, 1974:170).

In aansluiting by Hiltner word 'n kwalitatiewe onderskeid getref in die praksisbetrokkenheid van verskillende teologiese dissiplines:

Die fokus van die teologiese arbeid van eksegete, historici en dogmatici is nie primêr gerig op die praksis van die kerk nie, maar op die betekenispatrone en teologiese interpretasies van die kerklike praksis. Ook is die fokus op die apparaat wat die Christendom as sosiale beweging ontwerp het. Met hierdie apparaat poog die Christendom om sy legimiteit in die verlede te grondves en regulerend vir sy teenswoordige handelinge aan te wend.

Hierdie dissiplines maak die sinhorison oop wat in bestemde tekste van die teologiese oorlewering teenwoordig is en dui aan wat die betekenis en waarde van hierdie tekste is vir die huidige situasie. Hiltner beskou die arbeid van hierdie dissiplines as die "logic centred branch of theology".

Hierteenoor staan Praktiese Teologie as dissipline wat tot die "operation-centred branch of theology" behoort. Praktiese teologie is primêr gefokus op die praksis van die kerk. Die taak van Praktiese Teologie lê daarin om sake van belang in die teenswoordige kerklike handelinge te analiseer en die geanaliseerde situasie as opgawe en opdrag voor die deur van die ander teologiese dissiplines te lê. Andersyds tree Praktiese Teologie weer bemiddelend op om die aansprake van die teologiese oorlewering waaroor krities nagedink is weer terug te neem na die kerklike praksis. Omdat Praktiese Teologie nie oorgelewerde tekste, maar teenswoordige Christelikkerklike handelinge as sy uitgangspunt en doelpunt het, behoort dit 
metodologies volgens die analogie van hedendaagse handelingswetenskappe ingerig te word (vgl. Hiltner, 1958:28).

Wanneer Zerfass hierdie gedagtegang aan die hand van sy model verduidelik, toon hy aan dat Bybelse, historiese en sistematiese teologie primêr besig is met die kritiese konstruksie van die oorleweringsaansprake (4). Vanuit hierdie primêre aktiwiteit word deels spontaan (2) en deels in gesprek met die handelingswetenskappe (5) 'n invloed uitgeoefen op die prakties-teologiese teorieontwerp (9) en uiteindelik op die kerklike praksis (10). Hierteenoor is die primêre arbeid van Praktiese Teologie gerig op die voorbereiding (3) en implikasies (8) van situasie-analise (6) met die oog op prakties-teologiese teorieontwerp (9) en begeleiding tot 'n nuwe praksis (10) (Zerfass, 1974:70 e.v.)

\subsection{Enkele waarnemings oor die werking en implikasies van Zerfass se model}

Die model van Zerfass is nie ' $n$ statiese model nie, maar dui ' $n$ beweeglike proses aan wat opgebou is uit elemente van spanning, verandering en interaksie. Met hierdie inrigting van die praktiesteologiese proses as 'n beweeglike proses, trek Zerfass die volle konsekwensies van 'n handelingswetenskaplike benadering deur tot die Praktiese Teologie. Praktiese Teologie (as handelingswetenskap) is veral geïnteresseerd in aspekte wat in beweging is. Praktiese Teologie behoort dan tot die tak van die wetenskap wat hom nie besig hou met die vraag "wat en hoe iets is nie", maar met die vraag "wat gebeur en hoe dit kan gebeur" (vgl. Firet, 1968:125). Praktiese Teologie ondersoek die teologiese beweging wat op die mens gerig is en die mens in beweging bring. Dit is opvallend dat daar in die inrigting van Zerfass se model nie sprake is van eenrigtingverkeer wat bloot gereël word vanuit teorie na praksis nie, maar van 'n primêre beweging vanuit praksis via teorie na 'n nuwe praksis (vgl. 2.1). Hierdie kenmerkende beweging vanuit praksis, via teorie na nuwe praksis, verkry in die model van Zerfass die aard van 'n spanningsbeweging en gaan op in konflikbestuur. Dat die aanleiding vir die gang van die nadenke in die prakties-teologiese proses geleë is in die handelingspraksis van 'n bepaalde konkrete situasie in die kerk (en nie in die normatiewe beweging van prinsipiële teorie na praksis nie), is veelseggend. Spanning in die konkrete praksis van die kerk - en nie spanning tussen die openbaring in die Woord en die konkrete situasie nie - word as vertrekpunt geneem vir die gang van die nadenke. 
'n Verdere waarneming van die werking van Zerfass se model is dat die basiese beweging vanuit praksis, via teorie na nuwe praksis ingerig word in die konteks van wisselwerking en dan bepaald hermeneutiese wisselwerking (vgl. 2.2). In die proses van wisselwerking het die analise van die konkrete situasie 'n bepaalde hermeneutiese uitwerking op die teologiese tradisie. Die teologiese tradisie word opgeroep om sy denkmodelle en geldende norme vir handelinge opnuut in oënskou te neem en te herinterpreteer. Aan die ander kant het die teologiese tradisie in die proses van wisselwerking ook 'n invloed op die manier waarop die geanaliseerde situasie in 'n bepaalde rigting gestuur word. Die geanaliseerde situasie het geen intrinsieke handelingsaanwysings nie, maar moet ten opsigte van die implikasies daarvan eers getoets word aan en gekonfronteer word met die oorleweringsaansprake van die kerklike tradisie.

Die werking van Zerfass se model loop uit op 'n kringloop waarin die nuwe handelingspraksis van Praksis 2 opnuut weer getoets moet word en deur die proses van hermeneutiese wisselwerking verder gekorrigeer behoort te word. Die reformatoriese tema waarmee Praktiese Teologie hom besig hou, vind neerslag in 'n sikliese benadering waarin die status quo voortdurend gekorrigeer word.

Ten opsigte van die wesensbestemming van Praktiese Teologie as wetenskap, kan op grond van die werking van die model die waarneming gemaak word dat Praktiese Teologie deur Zerfass as integrasiewetenskap ingerig word met ' $\mathrm{n}$ bemiddelende en begeleidende taak. Praktiese Teologie staan enersyds tussen ander teologiese dissiplines en andersyds tussen sosiale wetenskappe as 'n soort "integrasiewetenskap" (vgl. Dingemans, 1989:200). Resultate van die ander teologiese dissiplines (Bybelse, historiese, sistematiese teologie) en die resultate van die handelingswetenskaplike ondersoek (waarin Praktiese Teologie die swaartepunt van sy arbeid vind), word met mekaar geïntegreer by wyse van prakties-teologiese teorievorming. Praktiese Teologie het dan soos dit uit die model van Zerfass blyk - 'n dubbele taak, naamlik om deur middel van ' $n$ handelingswetenskaplike fokus besig te wees met die voorbereiding en implikasies van situasie-analise, maar ook om integrasiewetenskaplik die proses van verandering in interaksie met die ander teologiese dissiplines te bemiddel en te begelei.

Ten opsigte van die verhouding met sosiale wetenskappe blyk dit uit die model van Zerfass dat hy primêr ' $n$ interdissiplinêre benadering volg. Die model word so ingerig dat ander teologiese dissiplines (Bybelse, historiese, sistematiese teologie) en sosiale wetenskappe 
met mekaar in gesprek tree as verteenwoordigers van verskillende invalshoeke tot dieselfde sosiale realiteit. Uit die inrigting van die model blyk dit dat Zerfass poog om sowel die teologiese insigte as die resultate en metodologie van die sosiale wetenskappe tot hulle volle reg te laat kom, sonder dat die een die ander oorheers. Wat Praktiese Teologie betref, blyk dit dat Zerfass 'n intradissiplinêre benadering volg in soverre as wat Praktiese Teologie in sy fokus en ondersoekmetodes nie primêr op oorgelewerde tekste gerig is nie, maar die teenswoordige Christelik-kerklike handelinge as sy uitgangspunt en doelpunt het. Juis op grond van laasgenoemde behoort Praktiese Teologie metodologies ingerig te word volgens die analogie van moderne handelingswetenskappe. Zerfass se handelingswetenskaplike inrigting van Praktiese Teologie bevat empiries-analitiese elemente (situasie-analise met die oog op die toetsing van die houdbaarheid van 'n bestaande handelingspraksis), sowel as hermeneuties-bemiddelende elemente (die interpretasie van die teologiese tradisie in wisselwerking met die gegewens soos dit blyk uit die geanaliseerde situasie).

Noudat 'n oorsig verkry is oor die ontstaan, werking en implikasies van die handelingswetenskaplike model van Zerfass, kan daartoe oorgegaan word om die aansluiting by en die gebruik van die model in 'n gereformeerde konteks te beoordeel.

\section{5. 'n Gereformeerde perspektief op Zerfass se model as korrektief vir die Christelik-kerklike praksis}

\subsection{Beoordeling en spesifisering vanuit die Soli Deo Gloria- vertrekpunt}

Daar is aangetoon hoe Zerfass se model die proses van nadenke laat neerslag vind in 'n primêre beweging vanuit praksis via teorie na 'n nuwe praksis. Ook is waargeneem dat die vertrekpunt geneem word in die spanningsvolle situasie van die konkrete kerklike praksis - en nie in die spanning tussen die Skrifopenbaring en die konkrete situasie nie. Vanuit 'n gereformeerde perspektief kan belangrike vrae gevra word oor hierdie inrigting van die prakties-teologiese proses:

- Wat gee aanleiding tot die handelingsdruk wat roep om 'n nuwe praksis?

- Is die aanleiding tot verandering in so 'n mate geleë in behoeftes van mense (soos dit in die konkrete situasie tot openbaring kom) 
dat die wil van God vir sy kerk (soos dit in die Skrif tot openbaring kom) na die agtergrond verskuif word?

- Het die kritiese rasionalisme, met sy vrae na die geldigheid van 'n bepaalde handelingspraksis, nie 'n groot invloed uitgeoefen op die manier waarop hierdie model ingerig is nie? In hierdie verband kan ook verwys word na die opmerking van Louw (1998:17) dat die hedendaagse praksis sterk bepaal word deur ekonomiese kragte wat die sosiale omgewing op 'n beslissende wyse beïnvloed.

Wanneer by hierdie model aangesluit word en dit gebruik word vir die inrigting van 'n prakties-teologiese studie behoort die navorser hom te verantwoord ten opsigte van die vraag of 'n kritieklose navolg van dié model sy studie nie vanaf 'n teosentriese fokus na 'n antroposentriese fokus verskuif nie. Vanuit 'n gereformeerde perspektief sou die vertrekpunt altyd gevind word in God se plan met alle dinge en die besondere rol van die kerk in hierdie plan. Vanuit hierdie hoek vind ook 'n subtiele aksentverskuiwing plaas in die manier waarop die belangrikste vraag van 'n prakties-teologiese studie geformuleer word. Die aksent verskuif naamlik vanaf ' $n$ vraag wat geformuleer word in terme van 'n meer effektiewe inrigting van 'n bepaalde handelingspraksis na 'n vraag wat geformuleer word in terme van hoe God se eer gedien kan word (Soli Deo Gloria) (vgl. Trimp, 1978:10). Dit sou dus nodig wees om in die vertikale dimensie van die model aan te toon hoe enige beweging vanuit 'n bepaalde handelingspraksis via teorie na 'n nuwe praksis, rekening hou met die wil van God. Ook moet aangetoon word dat beweging vanuit 'n sekere handelingspraksis in Christus gefundeer is en onder leiding van die Gees plaasvind.

\subsection{Beoordeling en spesifisering vanuit die eskatologies- voleindigende vertrekpunt}

Op 'n ander vlak sou ook die vraag gevra kan word of die model van Zerfass weens die tydbepaaldheid daarvan nie besig is om verouderd te raak nie. Die model het in die konteks van die sestigerjare van die vorige eeu ontstaan. Intussen het die denkwyse in die Westerse samelewing ontwikkel en word die fokus vandag op nuwe aksente gelê. Volgens Immink (2003:477) het daar 'n einde gekom aan die "wêreldverbetering"-denke van die sestigerjare van die vorige eeu. Wêreldverbetering was 'n reaksie op die wêreldmyding van die voor-oorlogse en na-oorlogse periode. Die élan van wêreldverbetering het intussen uitgesterf. Daar word minder idealisties en ideologies gedink. Oor wêreldverbetering word meer 
gepraat in psigososiale terminologie en minder in makroekonomiese en institusionele sin. Wanneer in 'n prakties-teologiese studie aansluiting gevind word by 'n model wat die verbetering van die praksis ten doel het, behoort daarmee rekening gehou word dat daar dikwels min kom van idealistiese veranderingsverwagtings. Praktiese Teologie word beoefen in ' $n$ gebroke werklikheid waarin die Gees dikwels bedroef word deur mense se volharding in geloofsongehoorsaamheid en geloofsonvolwassenheid. Voleindigende verandering kan alleen bewerk word deur die Een wat sê: Kyk, Ek maak alles nuut!

\subsection{Beoordeling vanuit die hermeneutiese grondreël dat die Heilige Skrif homself verklaar}

$\mathrm{Na}$ aanleiding van waarnemings wat gemaak is oor die kenmerkende hermeneutiese wisselwerking in die model, behoort die navorser wat van voorneme is om die model te gebruik, sy eie beskouing oor die aard van wisselwerking duidelik te omlyn. In die vasstelling van die aard van wisselwerking tussen die openbaring uit die Woord van God (en die interpretasie daarvan deur die kerklike tradisie) aan die een kant en die analise van die konkrete situasie waarin ' $n$ bepaalde handelingspraksis plaasvind aan die ander kant, sou dit nodig wees om die verhouding openbaring-ervaring duidelik te omlyn en te verantwoord. 'n Hermeneutiese beskouing kan daarin opgaan om - soos dit byvoorbeeld uit die hermeneutiese teologie van H.M. Kuitert blyk - godsdienstige geloof 'n saak van "benede" te maak: 'n saak van mense wat uitsprake maak oor God. In hierdie hermeneutiese benadering word die mens die subjek van die openbaringsgegewe. Die Skrif word dan gebruik om vas te stel hoe mense reageer op die openbaring - die reaksie van eerste getuies. In die latere kerklike tradisie word die Bybelse boodskap herformuleer en heraktualiseer op grond van ervarings wat mense in daardie tyd beleef. Wanneer die uiteindelike waarheid nog nie aan die lig gekom het nie, moet alle kerklike leer per definisie voorlopig wees. Kerklike leer is 'n soekontwerp wat die gevaar loop om met die verloop van tyd agter te raak. Latere ervaring sal die soekontwerp van oorgelewerde geloofsinhoud verifieer of falsifiseer (Kuitert, 1969:64 e.v.; vgl. Trimp, 1984:16 e.v.).

Teenoor 'n antroposentriese vertrekpunt stel die gereformeerde benadering 'n teologiese vertrekpunt waarin die openbaring vanuit God uitgaan, lig gebring word in die konkrete situasie deur die Woord en die mens opgewek word tot geloofsgehoorsaamheid aan die onveranderlike Woord van God, wat gister, vandag en tot in 
ewigheid dieselfde is. Openbaring breek deur die grense van menslike ervaringsmoontlikheid. Openbaring maak perspektiewe oop ver bo dit wat ons ooit kon bid of dink.

Voortvloeiend uit hierdie openbaringsbeskouing word met 'n Skrifbeskouing gewerk waar die Skrif en uitinge wat uit die Skrif uitgaan, nie afhanklik is van die mens wat dit interpreteer nie. Die Skrif verklaar homself (Sacra Scriptura sui ipsius interpretas). Vanuit so 'n beskouing word Skrifbeginsels nie bloot hanteer as 'n toepassing op die praksis nie, maar as 'n deurbreking van die praksis en selfs as 'n oordeel oor die praksis. Pieterse (1992:332) omskryf die hermeneutiese wisselwerking tussen die teologiese (Woord-teologie) en die konkrete handelinge in die lewensituasie van die gemeente (werklikheid) as 'n spanningsvolle interpolêre dialoog. Hierdie interpolêre verhouding behoort volgens hom nie dualisties te werk nie, maar behoort die dinamiek van die Woord in die werklikheid van die gemeente verbondsmatig saam te vat en te vertolk. Ongeag of die hermeneutiese verhouding tussen Skrif en situasie, openbaring en ervaring as wisselwerking of as interpolêre spanning of as kreatiewe spanning omskryf word (vgl. Kruger \& Venter, 2001:567), behoort altyd duidelik gemaak te word dat die primêre beweging vanuit die Skrif uitgaan. In hermeneutiese wisselwerking het die Woord die eerste en die laaste sê en dit wat vanuit die konkrete situasie van onder na bo gaan, het primêr te doen met geloofsverwondering oor die Woord en geloofsgehoorsaamheid aan die Woord. Geloof as gawe van God is die keersy van outonome subjektiwiteit. In geloof is die mens 'n antwoordende wese (Immink, 2003:475).

\subsection{Beoordeling vanuit die heilsrealisering deur die geloof in Christus alleen}

Die waarneming dat Zerfass se model die gang van praktiesteologiese nadenke in 'n kringloop van korrigering laat opgaan, behoort vergelyk te word met 'n eie benadering ten opsigte van die reformatoriese taak van Praktiese Teologie. Die vraag kan gevra word of die reformatoriese taak van Praktiese Teologie in die manier waarop die model ingerig is, nie vereng word nie. In 'n model wat opgaan in die transformasie van 'n gegewe situasie kan dit gebeur dat die Skrif selektief gelees word vanuit 'n hoek waar eintlik net gesoek word na die situasie se veranderingspotensiaal (Burger, 1991:61), terwyl heilsrealisering en voleindiging nie tot hulle volle reg kom nie. In 'n gereformeerde benadering word nie alleen rekening gehou met die sikliese gang om 'n bestaande praksis deur 
'n nuwe praksis te korrigeer nie, maar word sola fidei gefokus op Christus, deur Wie die handelingspraksis van die kerk met reddende krag oopgebreek word en uiteindelik sy voleindiging vind in 'n nuwe hemel en aarde. Denke word nie vasgevang in 'n oneindige, vermoeiende kringloop wat voortdurend sug na vernuwing nie, maar kan hoopvol gefokus word op 'n voleindigingspunt waarin alles waarlik nuut gemaak word. Deur geloof breek die krag van die toekoms met lewende hoop in die hede in en die handelingspraksis kan die aard begin toon van handelende mense wat besef dat hulle in Christus meer as oorwinnaars is. Aansluiting by en gebruik van Zerfass se model sou beperk wees tot prakties-teologiese studies waarin gefokus word op die noodsaak om 'n bestaande handelingspraksis in die kerk reg te stel. Korrigering is slegs een aspek van moontlikhede waarmee Praktiese Teologie hom in sy reformatoriese taak kan besig hou. Prakties-teologiese studies wat gerig is op voleindiging en die lewende hoop wat voleindigende geloofsdenke in die huidige handelingspraksis inbring, sou nie anders kan as om die studiegang volgens ' $n$ verruimde model in te rig nie.

\subsection{Praktiese Teologie is in wese 'n teologiese wetenskap}

Ten opsigte van die manier waarop die wesensbestemming van Praktiese Teologie in die model ingeklee word, is die waarneming gemaak dat Praktiese Teologie integrasiewetenskaplik ingeklee word. Sodanige inrigting kan Praktiese Teologie verskraal tot 'n strategie waarin resultate van ander dissiplines (hetsy teologiese dissiplines of sosiaal-wetenskaplike dissiplines) slegs toegepas word (Pieterse, 1992:331). Die heersende teologie bepaal self die doel en die prakties-teologiese wetenskap verskaf die middele om die doel te bereik (Dingemans, 1989:206). Waar die hooffokus van prakties-teologiese arbeid gerig word op handelingswetenskaplike ondersoek na die konkrete handelingspraksis in die kerk, kan die vraag gevra word of die teologiese kwaliteit van Praktiese Teologie as teologiese wetenskap nie in gedrang kom nie. As ' $n$ basisteorie slegs geformuleer word na aanleiding van die resultate van ander teologiese dissiplines en dit funksioneer as fasiliteerder tussen die sosiaal-wetenskaplike ondersoek en die teologiese ondersoek van die ander teologiese dissiplines, kan Praktiese Teologie daaronder ly weens 'n gebrek aan diepgang in eie, eerstehandse omgang met die Skrif. Zerfass se model word so ingerig dat dit die taak van ander teologiese dissiplines word om basisteoretiese merkers te gee, terwyl Praktiese Teologie slegs integrerend met die basisteorie werk en vanuit sy aard as handelingswetenskap primêr besig is op 
metateoretiese vlak en dan weer integrasiewetenskaplik besig is met begeleiding tot prakties-teologiese teorievorming (praktykteorie). In die inkleding van die studiegang behoort kennis geneem te word van Firet (1968:125) se onderskeid tussen twee dinamiese momente: die hermeneutiese moment (die Woord van God is gerig op verstaan, verheldering) en die agogiese moment (die Woord is gerig op leidinggewende verandering met die oog op lewensvernuwing) (vgl. Kruger \& Venter, 2001:566).

In 'n gereformeerde benadering behoort die teologiese kwaliteit van Praktiese Teologie ten alle koste beskerm te word deur die hooffokus van die teorievormende arbeid te laat val op die formulering van 'n Skrifgebonde basisteorie wat hermeneuties gerig word op die konkrete situasie (metateorie), en normatief en agogies gerig word op die vernuwing en voleindiging van die handelingspraksis van die kerk (praktykteorie).

\section{Samevatting}

Aansluiting by en gebruik van die basiese struktuur van Zerfass se handelingswetenskaplike model as korrektief op die Christelikkerklike handelingspraksis kan van groot waarde wees vir 'n prakties-teologies studie wat spesifiek gerig is op die regstelling van ' $n$ bestaande handelingspraksis. Al die relevante faktore wat ter sprake kom in die reformatoriese proses om 'n bestaande handelingspraksis te korrigeer, word op 'n duidelike wyse in een model saamgetrek. Enkele aksentverskuiwings en spesifiserings is egter nodig vir aansluiting by en gebruik van die model in ' $n$ gereformeerde konteks:

- Die fokus van die navorsingsvraag sal verskuif moet word vanaf 'n vraag wat geformuleer word in terme van 'n meer effektiewe inrigting van 'n bepaalde handelingspraksis (antroposentries), na 'n vraag wat geformuleer word in terme van hoe God se eer gedien kan word (teosentries).

- Hermeneutiese wisselwerking tussen Skrif en praksis sal sy vertrekpunt neem in die openbaring van God in sy Woord. Deur die Woord van God word lig gebring in 'n konkrete situasie en word die mens opgewek tot gehoorsaamheid aan die Woord. Vanuit die situasie sal geantwoord word deur geloofsverwondering oor die Woord en geloofsgehoorsaamheid aan die Woord. 
- Die reformatoriese gerigtheid van die arbeid sal nie vasgevang wees in 'n sikliese gang om 'n bestaande praksis deur 'n nuwe praksis te korrigeer nie, maar sal in die geloof gefokus wees op Christus deur Wie die handelingspraksis van die kerk met reddende krag oopgebreek word en uiteindelik sy voleindiging vind in 'n nuwe hemel en aarde.

- Die hooffokus van die teorievormende arbeid sal verskuif na die prakties-teologiese formulering van die basisteorie uit die Skrif wat in hermeneutiese wisselwerking gerig word op resultate wat uit die analise van die konkrete situasie verkry word (metateorie). Normatief sal die fokus agogies gerig word op die vernuwing en voleindiging van die handelingspraksis van die kerk (praktykteorie).

\section{Geraadpleegde literatuur}

BALLARD, P. 2001. Contemporary patterns in Anglo American Protestant Practical Theology. Praktiese Teologie in S.A., 16(2):1-16.

BASTIAN, H.D. 1965. Verfremdung und Verkundigung - gibt es eine theologische Informationstheorie? München: Kaiser.

BASTIAN, H.D. 1968. Vom Wort zu den Wörtern. Evangelische Theologie, 28(1):25-55.

BOHREN, R. 1975. Daß Gott schön werde - Praktische Theologie als theologische Ästhetik. München: Kaiser.

BROWNING, D.S. 1996. A fundamental practical theology - descriptive and strategic proposals. Minneapolis: Fortress.

BURGER, C. 1991. Praktiese teologie in Suid-Afrika. Pretoria: RGN.

DE KLERK, B.J. 1999. Die Heilige Gees en die Skriflesing in die samekoms van die gemeente. In die Skriflig, 32(2):165-186.

DE KLERK, B.J. \& NAGEL, C.J. 2004. 'n Beperkte empiriese ondersoek van kreatiewe prediking in die Gereformeerde Kerke in Suid-Afrika. In die Skriflig, 38(1):125-144.

DINGEMANS, G.D.J. 1989. Praktische Theologie als een academische discipline - een overzicht van ontwikkelingen in de praktische theologie met bijzondere aandacht voor de situatie in Nederland, Duitsland en die Verenigde Staten. Nederlands Theologisch Tijdschrift, 43(1):192-209.

DINGEMANS, G.D.J. 1996. Manieren van doen - inleiding tot de studie van de praktische theologie. Kampen: Kok.

DREYER, J.S. 2002. Theological normativity: ideology or utopia? Reflections on the possible contribution of empirical research. Praktiese Teologie in S.A., 17(2):1-20.

FIRET, J. 1968. Het agogisch moment in het pastoraal optreden. Kampen: Kok.

GROSSKOPF, O.H. \& LOTTER, G.A. 2003. "Gifts among the genders?" Some metatheoretical considerations. Praktiese Teologie in S.A., 18(2):13-32.

HEITINK, G. 1999. Practical Theology - history, theory, actions domains. Grand Rapids: Eerdmans. 
HEYNS, L.M. 1990. Models as facilitators of the traffic between theory and praxis. (In Heyns, L.M. \& Pieterse, H.J.C., ed. A primer in Practical Theology. Pretoria: Gnosis. p. 33- 37.)

HILTNER, S. 1958. Preface to Pastoral Theology. New York: Abingdon.

IMMINK, G. 2003. Het geloof en het leven - een theologie van de praxis. Praktische Theologie, 30(4):473-484.

JONKER, H. 1983. Theologische praxis - problemen, peilingen en perspektieven bij kenterend getij. Nijkerk: Callenbach.

JONKER, W.D. 1968: Theologie en praktijk - ein peiling van het theologisch karakter van de diakoniologische vakken. Kampen: Kok.

KEARNEY, R. 1984. Dialogues with contemporary continental thinkers - the phenomenological heritage. Manchester: Manchester University Press.

KRUGER, S.F. \& VENTER, C.J.H. 2001. Die verhouding tussen Psigologie en Praktiese Teologie - aspekte van die onderlinge waarde van dié verhouding. In die Skriflig, 35(4):557-573.

KUITERT, H.M. 1969. Verstaat gij wat gij leest? - over de uitleg van de bijbel. Kampen: Kok.

LOUW, D.J. 1998. Die konsep "Prakties-teologiese spiritualiteit" binne 'n konteks van postmodernisme en globalisering. Praktiese Teologie in S.A., 13(2):16- 25.

LOUW, D.J. 2003. The paradigmatic revolution in practical and pastoral theology: from metaphysics (substantial thinking) to empirism (experiental thinking); from theism to theopaschitism (hermeneutical thinking). Praktiese Teologie in S.A., 18(2):33-57.

PIETERSE, H.J.C. 1992. Woord en werklikheid in die moderne Praktiese Teologie. In die Skriflig, 26(3):325- 335.

PIETERSE, H.J.C, GREYLING, S. \& JANSE VAN RENSBURG, H.J. 2004. Die implikasies van $P$. Ricoeur se handelingsteorie vir die homiletiek. Praktiese Teologie in S.A., 19(1):89-118.

TRIMP, C. 1978. Inleiding in de ambtelijke vakken. Kampen: Copieerinrichting V.D. Berg.

TRIMP, C. 1984. "Ervaring" in de moderne theologie - "ervaring" en "openbaring" by H. Berkhof en H.M. Kuitert. In die Skriflig, 18(1):9-25.

VAN DER VEN, J.A. 1990. Entwurf einer empirischen Theologie. Kampen: Kok.

VENTER, C.J.H. 1996. Uitkringende liefdesbetoon: kommunikatiewe handelinge in diens van die onderlinge liefdesgemeenskap in die kerk. Pretoria: RGN.

VENTER, C.J.H. 2004. Die predikant wat houe uitdeel - die gemeente as teiken. In die Skriflig, 38(3):429-449.

ZERFASS, R. 1974. Praktische Theologie als Handlungswissenschaft. (In Klostermann, F. \& Zerfass, R, Red. Praktische Theologie Heute. München: Kaiser. p. 164-177.)

\section{Kernbegrippe:}

korrektief op Christelik-kerklike praksis

prakties-teologiese teorievorming

Zerfass: handelingswetenskaplike model

Zerfass se model: gereformeerde perspektief op 


\section{Key concepts:}

correcting Christian ecclesiological praxis

practical-theological theory-formation

Zerfass's model: reformationed perspective on

Zerfass's operational scientific model 
